ORIGINAL ARTICLE

\title{
Jane Austen's lifelong health problems and final illness: New evidence points to a fatal Hodgkin's disease and excludes the widely accepted Addison's
}

A Upfal

J Med Ethics; Medical Humanities 2005;31:3-11. doi: 10.1136/jmh.2004.000193

Jane Austen is typically described as having excellent health until the age of 40 and the onset of a mysterious and fatal illness, initially identified by Sir Zachary Cope in 1964 as Addison's disease. Her biographers, deceived both by Cassandra Austen's destruction of letters containing medical detail, and the cheerful high spirits of the existing letters, have seriously underestimated the extent to which illness affected Austen's life. A medical history reveals that she was particularly susceptible to infection, and suffered unusually severe infective illnesses, as well as a chronic conjunctivitis that impeded her ability to write. There is evidence that Austen was already suffering from an immune deficiency and fatal lymphoma in January 1813, when her second and most popular novel, Pride and Prejudice, was published. Four more novels would follow, written or revised in the shadow of her increasing illness and debility. Whilst it is impossible now to conclusively establish the cause of her death, the existing medical evidence tends to exclude Addison's disease, and suggests there is a high possibility that Jane Austen's fatal illness was Hodgkin's disease, a form of lymphoma.

Correspondence to: Annette Upfal, School of English, Media Studies and Art History, The University of Queensland, Brisbane Qld 4072, Australia; a.upfal@uq.edu.au

Accepted for publication 1 March 2005
$\mathrm{T}$ he spectre of disease and early death hung over Jane Austen in the final 2 years of her life, as she continued to work on her novels, whilst her body weakened and wasted and ultimately failed her at the age of 41 . The nature of her illness had baffled her medical advisors, and still remains a subject of controversy. Current medical opinion, biographers, and encyclopaedic reference all lean towards a diagnosis of Addison's disease, which involves destruction of the adrenal glands, but other medical opinion surmises that Jane may have been suffering from Hodgkin's disease, a form of cancer. Both diseases were unidentified and untreatable in Austen's lifetime, and the outcome was always fatal.

The futility of this death from an illness that now offers recovery, with the image of a dying writer struggling to use a pencil, when a "pen was become too laborious" ${ }^{\prime 1}$ and above all, regret for the novels that were yet to be written, have added a sense of pathos to Austen's iconic status. Biographers generally date the onset of this fatal illness, to the beginning of 1816, and close to her 40th birthday. ${ }^{2}$ She would live just 18 months more. The mythic appeal of a 'genius whose life is cut tragically short' magnifies the contrast between the healthy, vital woman, struck down by fatal illness at the height of her creative powers, and the sad, wasted figure she became. Biographers have also tended to follow this line and ignore or trivialise previous episodes of illness that are documented in Jane's letters. Deirdre Le Faye, for example, a pre-eminent Austen authority, remarks that "up to the end of 1815, Jane had been remarkably free from ailments." She did qualify this, however, by adding "So far as is known". ${ }^{3}$ In fact a medical history is threaded through the surviving Austen letters, which reveals that she suffered other, and unusually severe and debilitating illnesses, and was particularly susceptible to infection. There were also episodes of a chronic conjunctivitis that began in her early twenties, and became increasingly frequent in later years, impeding her ability to write. Despite traditional accounts, this was not a case of a healthy person being suddenly struck down with a fatal illness. New medical evidence suggests that Jane was already suffering from an immune deficiency and fatal lymphoma in January 1813, when her second and most popular novel, Pride and Prejudice, was published. Four more novels would follow over the next 5 years, written or revised in the shadow of her increasing illness and debility. The final novel, Persuasion, was published in January 1818. But Jane had died 6 months earlier on 18 July 1817, and a fragment of a new novel lay abandoned in her writing desk. Whilst it is impossible now to conclusively establish the cause of her death, the existing medical evidence tends to exclude Addison's disease, and suggests there is a high possibility that Jane's fatal illness was Hodgkin's disease, a form of lymphoma.

The importance of a close examination of Jane Austen's medical history goes far beyond the satisfaction of establishing a retrospective diagnosis for her various symptoms, and intended for an audience of medical professionals. Its significance should be seen rather against a context of the scant documentary evidence of Jane's life, and an intense public interest in everything relating to her. The first biography, a Memoir, was published in 1870. The early trickle of interest since that date has become an avalanche of titles concerning her in the past 50 years, with every known aspect of her life and work placed under scrutiny. But through it all, Jane Austen, the person, remains an enigmatic and elusive figure. 
There is so much in her life that is missing. She kept no diaries or personal journals, and her most revealing letters were destroyed by her sister Cassandra after her death. Other material was lost or distorted by family members half a century later, in an effort to present a sanitised version of her life, and it is very unlikely now that any new letter or personal remembrance will emerge. The biographer is left to rescan the existing inadequate evidence, and sometimes, very rarely as in this case, the letters yield up something exciting and new. These seemingly nondescript scraps of medical history lead to insights that transcend the barriers of Cassandra's ruthless culling, and at times are startling and almost voyeuristic in their intimacy. Knowledge of the illness provides the detail of symptoms that would have been excluded from the letters. Le Faye, the most recent editor of Jane Austen' Letters, notes that some letters have a line cut out, relating to "physical ailment" and considers that Cassandra simply destroyed any letter that "described physical symptoms rather too fully". ${ }^{4}$ A detailed medical history reveals the extent to which illness impacted on Austen's life, on family relationships, on her ability to work, and even left its traces on the last manuscripts. It offers a tangible impression of Jane, the woman, coping with illness whenever possible, by cheerfully dismissing it from her mind, and later struggling to maintain her own good humour and a sense of normalcy in her life, as the symptoms of disease overwhelmed her body.

Illness was to dominate the first few months of her life as well as the last. Her nephew and first biographer, JE Austen Leigh, faced with an almost total lack of family letters or other evidence was forced to admit that he knew "little of Jane Austen's childhood." ${ }^{\prime 5}$ By some quirk of chance, a family letter describing her birth at Steventon Rectory on 16 December 1775 has survived, and forms an important, first suggestion of a serious medical problem. Jane was born 4 weeks overdue, according to her parents' calculations. Her father even made a joke about it in this letter to his sister-inlaw, Susanna Walter.

\section{Dear Sister, \\ You have doubtless been for some time in expectation of hearing from Hampshire, and perhaps wondered a little we were in our old age grown such bad reckoners but so it was, for Cassy certainly expected to have been brought to bed a month ago. ${ }^{6}$}

But was it just a case of bad reckoning? It seems very unlikely considering that the Austens had six children already and from the evidence of this letter, had never previously miscalculated their dates. Birth was always a worrying and disruptive time for any family. Childbirth was managed at home without medical assistance, and even if the birth were trouble free, the new mother would be kept in bed for at least 2 weeks. Somebody else would have to run the household and arrangements were made well in advance. It was vital to these arrangements that the estimated confinement date was as accurate as possible. It was simply too important to get wrong.

A normal pregnancy is calculated as 40 weeks from the last menstrual period, and over $80 \%$ of births occur between the 38th and 42nd week. Only 5\% continue, as in Jane's case, after the 43rd week. ${ }^{7}$ A pregnancy that continues after 42 weeks is considered postdate, and the fetus may be severely at risk. There is a heightened risk of birth injury or death, and over $20 \%$ of postdate infants show signs of wasting of tissues - a medical condition known as postmaturity, which in severe cases can be fatal. If a pregnancy is postdate, the modern obstetrician will usually order tests to monitor the fetus and to decide whether or not to intervene. In the $18^{\text {th }}$ Century it was a matter of letting nature take its course.

The postmature infant was described by the classic authority, SH Clifford, ${ }^{8}$ as showing signs of late-onset wasting of tissue, due to placental insufficiency. If a pregnancy is prolonged, the placenta begins to degenerate and the fetus may receive inadequate nutrients from the mother, resulting in soft tissue wasting. ${ }^{9}$

According to her father's description, Jane Austen seemed normal at birth, and this is quite consistent with postmaturity:

Last night the time came, and without a great deal of warning, everything was soon happily over. We have now another girl, a present plaything for her sister Cassy and a future companion. She is to be Jenny and seems to me as if she would be as like Henry, as Cassy is to Neddy. ${ }^{10}$

The fetus continues to grow in the womb and the infant is long and thin, with some tissue wasting. It is interesting that George Austen noted a close resemblance to his fourth son, Henry, born 4 years earlier. Both children had hazel eyes, but Henry was also very tall for his age. ${ }^{11}$ and the father must have noticed that this baby too, seemed quite long.

A close inspection of the baby may have shown signs of tissue wasting, which caused the skin to hang in loose folds, especially on the arms and legs. There would be signs in behaviour as well, including listlessness, irritability, and feeding problems which would persist for some time, with the baby failing to thrive, and incessantly irritable. Various studies reveal the stress placed on the mother-child relationship, with postmature babies described as "difficult" by their mothers. They also had more severe illnesses in the first year of life. These findings also applied to postdate babies who did not show obvious signs of tissue wasting at birth, and the problems were more severe for those born after 43 weeks (Sims, p 291). ${ }^{7}$

Jane would have been frail and probably ill in the first months of her life and this seems to be confirmed by her christening in the church being delayed until she was almost four months old (Le Faye, p 27). ${ }^{3}$ According to Mrs. Austen's child-rearing practice, the baby was weaned at 3 months, and then sent to a "good woman's" for at least a year, a farm worker's wife, who lived in the nearby village of Deane. ${ }^{12}$ Jane was moved there sometime after her April christening, and certainly before the first week of June, when her parents were on holiday in London. ${ }^{13}$

The circumstances of Jane's birth raise the possibility of an immune deficiency, related to postmaturity, (Beers, p 1026) ${ }^{9}$ and her medical history of both unusually severe infections and chronic infection, is consistent with an immune disorder. But there is also a compelling argument against this. A child with an immune deficiency in the 18th Century would be extraordinarily lucky to survive to adult life. Most disorders that present from birth would render her susceptible to fatal chicken pox, or if she were lucky enough to survive, she would have been at the very least severely disabled by it. One factor, however, that might have preserved the young Jane's life was the isolated location of her family home, and consequent lack of exposure to childhood epidemics.

Steventon, Jane's loved home for the first 25 years of her life, was a remote village in the Hampshire Downs, about 7 miles south-west of Basingstoke. Access was by a narrow and winding dirt lane, full of potholes, and in wet weather became virtually impassable. The village itself was just a straggle of farm labourers' thatched cottages, each with its 
own small garden, and set in a pretty, wooded valley close to a stream and the village green. The rectory was a short distance from the end of the village, and stood on the corner of a 3-acre block, with its own dairy and small farm, and a tiny stone church high on the hill behind it, just glimpsed behind a screen of sycamores and elms.

Reverend George Austen leased a nearby 200-acre farm as well as farming his own glebe land. Mrs Austen had her dairy, poultry yard, piggery, vegetable garden, and beehives to supply the house. Bread was baked, and beer was brewed and stored in the cellar, together with a large supply of Mrs Austen's honey mead and some homemade wine. The rectory's self-sufficiency extended to the education of the children. The Austen boys were educated at home by their father, until entering university or the navy. Apart from two brief periods, he supervised the formal education of his daughters as well. The Austen biographer Claire Tomalin notes that in an age when "few families were spared the deaths of several children," the Austens did not lose a single one of their eight children (Tomalin, p 6). ${ }^{2}$

According to family tradition, Jane did become dangerously ill however, within a few months of being sent away to school. In April 1783, Jane, aged 7 and Cassandra, 10, were sent with their 12 year old cousin Jane Cooper to Oxford, to board with Mrs Ann Cawley, the widowed sister of Dr Cooper. Sometime later in the year Mrs Cawley moved her few pupil boarders to Southampton and was soon in the midst of an epidemic of "putrid fever", which was raging in this town by late August. Jane and Cassandra were both infected, but Mrs Cawley did not inform their parents (Le Faye, pp 47-49). ${ }^{3}$ Fortunately, Jane Cooper wrote to her own mother, who came immediately in her carriage to rescue all three and move them to her home in Bath. ${ }^{14}$ In some accounts both Mrs Austen and Mrs Cooper arrived to take their daughters home, but all agree that Jane Austen nearly died of this illness. In one version her life was saved by a remedy that the mothers brought with them. ${ }^{15}$

The "putrid fever" was in fact epidemic typhus, brought to Southampton that August by troops returning from service in Gibraltar (Le Faye, p 48). ${ }^{3}$ It is associated with cramped, insanitary conditions, and transmitted to humans in faeces of the human body louse. The symptoms include a constant headache and high temperature. About the fourth day the characteristic pink spots appear and rapidly darken and cover the whole body, only excluding the face, palms and soles of the feet. After 14 days, in uncomplicated cases, the temperature drops and the patient spontaneously recovers. The disease can be extremely serious in adults, and mortality increases with age, and is as high as $60 \%$ in persons aged 50 years or more (Beers, p 1228). ${ }^{9}$ Mrs Cooper was 47 years of age, and became fatally infected and died at her home in Bath on October 25th. In these fatal cases, death occurs from heart failure about day 14 of the illness. ${ }^{16}$

Mrs Cawley may have been negligent in not contacting the Austens, but perhaps she was aware that this disease is characteristically mild in children up to the age of ten. ${ }^{17}$ In any case, it would have been out of the question to take the girls home to the rectory, where they might introduce the infection to their brothers, or worse still, Mr Austen's 3 or 4 pupil boarders. The fear of infection in an age when no adequate treatment was available, is reflected in Sense and Sensibility in the Palmer family's immediate abandonment of their home when Marianne Dashwood's illness is described by the apothecary as "having a putrid tendency" and he allows "the word 'infection' to pass his lips."18 Mrs Palmer had left with her baby within the same hour.

No other scrap of medical evidence remains from Jane's childhood. The major resource for a medical history consists of her own surviving letters, including 97 to her sister
Cassandra, written over a 20 year period. Unfortunately, these only date to 1796, when Jane was already aged 20. Despite Cassandra's censorship, these letters, supplemented by other evidence, do provide medical insights, and reveal for example that Jane suffered from chronic conjunctivitis, with the first episode occurring in January 1799, when she was aged 23:

\section{Wednesday - I have had a cold and weakness in one of my eyes for some days, which makes writing neither very pleasant nor very profitable, and will probably prevent my finishing this letter myself. My Mother has undertaken to do it for me. ... \\ This complaint in my eye has been a sad bore to me, for I have not been able to read or work in any comfort since Friday, but one advantage will be derived from it, for I shall be such a proficient in music by the time I have got rid of my cold, that I shall be perfectly qualified in that science at least to take Mr Roope's office at Eastwell next summer. ${ }^{19}$}

In a letter written 2 weeks later, the problem had worsened, and spread to both eyes, ${ }^{20}$ indicating a viral infection. ${ }^{21}$ The first symptoms would seem like a "cold in the eye" with redness, watering, and itching, followed by sensitivity to light, (photophobia), and discomfort that could quickly become severe. The eyelids would look sore and swollen. This condition is often called "red eye" because of bleeding under the conjunctiva, and the white of the eye becomes bright red either in part, or totally (Macpherson, p 214). ${ }^{16}$

The discomfort of her eye did not prevent her from attending a ball a few nights later, but her account of this ball contains the rueful comment "I do not think I was very much in request-People were rather apt not to ask me till they could not help it;-One's consequence you know varies so much at times without any particular reason." ${ }^{22}$

Biographers have seized upon this statement as evidence that Jane, unlike the heroines of her novels, was physically unattractive. But a young lady at a ball who was suffering from the 'red eye' was unlikely to be 'very much in request'. It not only affected her appearance. Her partners would be concerned about catching a possible infection. No wonder gentlemen were 'apt not to ask till they could not help it.' Her last comment gives an insight into the way she viewed her own illness. She had dismissed the problem of her sore eye so effectively from her mind, she was unconscious of its effect on others.

She attended another ball the following week, with a predictable aggravation of her symptoms.

\section{My eyes have been very indifferent . . . keeping them so many hours open on Thursday night, as well as the dust of the ball-room, injured them a good deal. I use them as little as I can, but you know and Elizabeth knows, and everybody who ever had weak eyes knows, how delightful it is to hurt them by employment, against the advice and entreaty of all one's friends. ${ }^{23}$}

There is no cure for the virus, and treatment, then, as now, would focus on relief of symptoms, and avoiding further environmental irritants. Cold compresses and lubricants might be used, and the patient restricted to a dark environment. Recovery is usually spontaneous within 3 to 6 weeks. But in severe cases, that continue longer, there is inflammation of the cornea (keratitis), with marked photophobia, pain in the eyes, and some temporary blurring of vision (Barza, p 799). ${ }^{21}$ 
Jane's case must have been severe, because there is a reference to her eyes in the next surviving letter, written 4 months later, a day after her arrival in Bath on a family visit. "I find no difficulty in doing my eyes." ${ }^{24}$ This comment implies that Cassandra had been acting as nurse, and treatment for the conjunctivitis was still necessary.

The January letters describe the onset of acute conjunctivitis. By May, the infection had become chronic, and would persist, with remissions and recurrences over the years. At first there might be long gaps between recurrences, and the attacks would never be as long or severe as that first episode.

In the final years of her life, the recurrences would be more frequent and disabling. In September 1813, she was staying with her brother Henry at his house in London, and there is the one exasperated comment. "My eyes are quite tired of dust and lamps." ${ }^{25}$ Her niece Caroline Austen, who as a child often visited the Austen cottage at Chawton, also remembered Aunt Jane having problems with her eyes:

She could throw the spilikens for us, better than anyone else, and she was wonderfully successful at cup and ballShe found a resource sometimes in that simple game, when she suffered from weak eyes and could not work or read for long together. ${ }^{26}$

Years earlier, in that first episode of acute conjunctivitis, Jane had expressed her frustration at not being able to read or work as she wished. But she was a young woman then, with hopes and interests quite apart from her writing. At Chawton, her writing and books was the centre of her life. She tried to ignore the increasing symptoms of her disease, and continued to write, only to be defeated at times by episodes of conjunctivitis, when the work had to be put aside.

The first major period of creative writing was at Steventon, although her work was not published until many years later. Jane was aged 20, the same age as Elizabeth Bennet when she wrote the first draft of Pride and Prejudice. The early versions of Sense and Sensibility and Northanger Abbey were also written in this period. According to family tradition, Jane, then aged 25, was so distressed to leave Steventon that she fainted on being suddenly told that her father was retiring and they were moving immediately to Bath. ${ }^{27}$ After their arrival in May 1801, there is a gap of more than 3 years in the letters, a sure sign of problems, which Cassandra censored. Mr Austen died in January 1805, leaving his widow with a tiny income, which was supplemented annually by her sons. Jane herself was penniless. The three Austen women had no settled home, and were expected to save expenses by making long visits amongst their relatives. ${ }^{28}$

On 2 July 1806, they made a final move from the cheap lodgings in Bath, and, as Jane later expressed it, "with what happy feelings of escape!" ${ }^{\prime 29}$ The trio then set off on a round of family visits, where Jane became infected with an unusually severe case of pertussis or whooping cough, whilst staying with their rich Cooper relatives in Staffordshire. The Austens arrived on 14 August, and remained for about 5 weeks, as one by one, the young Cooper children went down with this illness (Le Faye, pp 157-8). ${ }^{3}$ In this case there was no question of leaving to escape the infection. Whooping cough was then overwhelmingly a disease of babies and young children, and adults were not considered to be at risk. The disease is very uncommon after the age of ten (Macpherson, p 634). ${ }^{16}$ If an adult is infected, the symptoms are usually mild, and described as catarrhal, and the duration of the illness is short and considered as "troublesome, but rarely serious" (Beers, p 2308). ${ }^{9}$

Towards the end of their stay, Jane contracted the infection, and by the time the Austens reached their new lodgings in Southampton on 10 October, she was becoming progressively worse.

Whooping cough usually resolves within 3 to 4 weeks, but severe cases can persist up to 3 months. As the illness progresses to the second or spasmodic stage, the patient develops the frequently recurring attacks of violent and convulsive coughing, followed by the whoop, a loud and distinctive in drawing of breath. Large amounts of mucus are expelled and there is frequent vomiting. This stage usually lasts 2 weeks, but in severe cases can continue for more than a month, and often with respiratory complications, including broncho-pneumonia (Beers, pp 2306-8). ${ }^{9}$

There is one surviving reference by Jane Austen to this illness, in a letter written 2 months later to Cassandra:

\section{A few days ago, I had a letter from Miss Irvine ... She supposes my silence may have proceeded from resentment of her not having written to inquire particularly after my hooping cough, and [...]. She is a funny one. ${ }^{30}$}

Miss Irvine was a distant relative and family acquaintance who lived in Bath. If news of Jane's whooping cough had circulated even amongst her acquaintances in Bath, she must have been seriously ill, and her own family had been concerned for her recovery. The second stage of the illness was severe and prolonged enough for Cassandra to send out anxious letters to family members and friends, and for letters of enquiry to be made to Southampton about her progress. Miss Irvine obviously felt guilty that she had not "inquired particularly."

Jane's letters from Southampton show that in October 1808 she suffered another infective illness, which may also have become chronic.

\section{Saturday, October 1-Mr Lyford called on tuesday to say that he was disappointed of his son and daughter's coming, and must go home himself the following morng;- and as I was determined that he should not lose every pleasure I consulted him on my complaint. He recom- mended cotton moistened with oil of sweet almonds, and it has done me good. - I hope therefore to have nothing more to do with Eliza's receipt than to feel obliged to her for giving it as I very sincerely do. ${ }^{31}$}

The complaint is revealed in her next letter as being with her ear, and she mentioned hearing loss. Mr Lyford was the elderly surgeon who had looked after the Austens at Steventon, and knew the family very well due to his frequent attendances on Mrs Austen. His call on them at Southampton was a social visit. It is interesting the way Jane trivialises her need for medical advice, and jokes that it is all for Mr Lyford's benefit. In fact her symptoms had been severe and prolonged enough for Cassandra to enclose a suggested remedy with the letter Jane had received that day from Godmersham in Kent.

Jane was almost certainly suffering from otitis externa, an infection of the outer ear, and possibly associated with a painful boil in her ear. Her symptoms would have included itching and severe pain accompanied by a foul smelling discharge. There would be a gradual onset of hearing loss as the ear canal became swollen and filled with debris from the discharge (Beers, p 669). ${ }^{9}$ These symptoms had persisted for more than 2 weeks in her case, and must have been very distressing.

If the itching is treated, the inflammation will usually subside. The modern treatment would probably include removing the infected debris, "followed by careful packing of the external ear with some soothing lotion" (Macpherson, p 182).$^{16}$ This is essentially the same treatment that Mr Lyford 
prescribed. Oil of sweet almonds is a soothing and nonallergenic oil that is still used in alternative medicine to treat eczema or dermatitis. Mr Lyford's advice was to pack the ear with a piece of cotton material that had been moistened with the oil. The treatment was effective. A week later, Jane described herself as cured. "I am much obliged to you for enquiring about my ear, and am happy to say that $\mathrm{Mr}$ Lyford's prescription has entirely cured me. I feel it a great blessing to hear again." ${ }^{32}$ There are no further references to ear problems in her letters, although there were probably recurrent episodes of otitis. But she could now manage the infection and treat the symptoms as soon as they appeared.

Jane's history of unusually severe and chronic infections suggests an immune deficiency or perhaps the presence of some underlying infection such as Tuberculosis, which was then very common. In early Tuberculosis, the disease may remain latent for years or have no overt symptoms (Macpherson, p 601). ${ }^{16}$ But in the absence of further evidence, this issue cannot be resolved, and remains speculative.

Early in 1809 Jane's immensely wealthy brother Edward Austen Knight finally offered his mother the rent free occupancy of one of the houses he owned in Chawton village, close to his own estate. It was Jane's first settled home in the 8 years since leaving Steventon Rectory, and she lived there for the rest of her life. Her novels were published in this Chawton period, with Sense and Sensibility appearing in October 1811. There is a gap in the letters from January 1809 to April 1811, and again from June 1811 until the end of October, 1812. The letters that Cassandra destroyed may have included references to new medical problems, and it is possible that Jane contracted her fatal disease during this period. The nature of this disease remains controversial, and apart from the widely accepted Addison's disease, other possibilities might include leukemia, Hodgkin's disease, non Hodgkin's lymphoma, Tuberculosis, and systemic Vasculitis. But the evidence provided in Jane's letters of 1813, points to the presence of a lymphoma, possibly Hodgkin's disease.

In January 1813, Pride and Prejudice was published, and a few months later Jane was experiencing symptoms of severe neuralgia, mainly documented in the diary of her niece, Fanny Knight. Edward and his family occupied the Great House at Chawton that summer whilst their main residence, Godmersham, was being painted. The Great House was just a short walk from the Austen cottage, and there are frequent references to Aunts Jane and Cassandra in the diary. On 18 July there is an entry of Aunt Jane suffering from "a bad face ache," and episodes of pain continue for at least the next 2 weeks. On 2 August Fanny notes that Aunt Jane "slept here and suffered sadly with her face." ${ }^{\prime 33}$

These episodes of neuralgia persisted. On 15 September, Jane had just arrived at her brother Henry's house in London with the Knights and would continue with them to Godmersham. The following day she wrote reassuringly to Cassandra that she had "no pain in my face since I left you. ${ }^{\prime 34}$ But a week later, at Godmersham, she admitted that the pain had returned, and "rather severer than it had been lately. This has worn off however and I have scarcely felt anything for the last two days". ${ }^{35}$

These symptoms describe a facial or trigeminal neuralgia associated with a previous infection of herpes zoster or shingles. This most severe form of neuralgia involves any one of the three divisions of the trigeminal nerve of sensation to the face. In herpes zoster, a virus invades the ganglia of the nerves, causing inflammation, and the resulting severe pain. Sometimes however, there is post herpatic pain that may recur over months or even years. In cases of immune deficiency, the acute stage of the infection may exceed
2 weeks, and the post herpatic pain is likely to persist longer and to be more severe (Beers, pp 1294-5). ${ }^{9}$

Herpes zoster is caused by the varicella-zoster virus, the same virus involved in chicken pox, but zoster is a disease of adults rather than children. Zoster occurs most often in immune-depressed or elderly persons. "Most adults who acquire the disease have had chicken pox in childhood" (Macpherson, p 275). ${ }^{16}$

Fanny Knight's younger sister Lizzie also remembered her aunt's sufferings with neuralgia. She described how sometimes she saw Aunt Jane walking along the path from Chawton village to the Great House, and obviously in pain, "with head a little to one side, and sometimes a very small cushion pressed against her cheek, if she were suffering from face-ache, as she not unfrequently did in later life" (Le Faye, p 27). ${ }^{33}$

Jane Austen's neuralgia affected the second division of the nerve and the pain would have been focused in the cheek and upper jaw. The pain affected one side of the face, and would be episodic, sometimes recurring about the same time each day whilst the attack lasted. Pain could also be precipitated by cold, or by taking a mouthful of hot or cold fluid. One medical text describes the pain as "devastating", and that for some patients who suffer frequent attacks, "the pain may be so intolerable as to make life a burden" (Macpherson, p 598). ${ }^{16}$

Jane was a very private person, and the pain must have been intense for her to walk out in public with a cushion pressed to her face. It also shows the level of her determination to disregard pain and illness. Most people would have remained at home and tried to relieve the symptoms. She continued her social engagements with her family, even though the walk to the Great House was enough to bring on the pain. There was pain every day, but that didn't stop her from making the journey to London and Godmersham. Far from feeling that life was a burden, the letters she wrote in the midst of the attack are quite cheerful. In that first letter from Godmersham, she is in "high glee" and "delighted." The letter begins and ends with a joke. ${ }^{36}$

Herpes zoster is very unusual in a young person, and indicates a pre-existing immune deficiency, associated with a lymphoma, such as Hodgkin's disease. In Jane's case, this must have pre-dated 1813. It is even possible that Jane already had a fatal lymphoma when her first novel, Sense and Sensibility was published in October 1811.

The herpes zoster virus can be activated by systemic disease, particularly Hodgkin's disease. Infections with herpes zoster are common in patients with this disease. ${ }^{37}$ The relationship is so pronounced that one study recommends that patients diagnosed with Hodgkin's disease be educated in early self-diagnosis of herpes zoster in order to receive prompt treatment. ${ }^{38}$ Hodgkin's disease is a form of cancer, and in Jane's time, there was no possible treatment. There is persuasive evidence that Jane suffered from Hodgkin's disease, and within a few years it would end her life.

Recent medical evidence suggests a close association between Hodgkin's disease and a previous history of infectious mononucleosis (glandular fever). ${ }^{39}$ Glandular fever is commonly described as the "kissing disease" which is hardly compatible with the familiar image of Jane as a prim and inexperienced spinster. In fact that image is very misleading. In her youth, at Steventon, "she was established as a very pretty girl," (Austen, p 5) ${ }^{26}$ and attended balls and assemblies at the age of sixteen. The few surviving letters of her early twenties suggest that Jane was quite adept at lighthearted flirtations. There is a reference to one unwanted admirer trying to steal a kiss, whilst another tried to trap her alone with him, and in another letter she has been reproved 
by Cassandra for openly flirting with a young man at a private ball. One rather malicious former neighbour described Jane in the Steventon years as "the prettiest, silliest, most affected husband-hunting butterfly she ever remembers" (Le Faye, p 81). ${ }^{3}$ Glandular fever is more common among adolescents aged 15-17," (Macpherson, p 381) 16 $^{16}$ and whilst no records remain for those years of her life, it cannot be excluded.

Hodgkins disease, or lymphadenoma is a "condition in which the lymphatic glands all over the body undergo a gradually progressive enlargement" (Macpherson, p 277). ${ }^{16}$ The cause is unknown, but there is evidence suggesting an association with a pre-existing immune deficiency. ${ }^{40}$ As the disease spreads there can be a wide range of symptoms, including gastric and bone involvement. There is a considerable degree of anaemia, and the patient becomes progressively weaker. The progress of the disease can be slow or intermittent, with periods when the patient feels some improvement. The outcome however, before modern chemotherapy and radiotherapy, was always fatal.

In 1814, the letters are cheerful as ever, although once again a small batch of letters have been destroyed. Pride and Prejudice had proved a great success and Mansfield Park was published in May. Jane also began writing a new novel, Emma, in January. Her brother Henry acted as her agent in negotiations with publishers and Jane needed to visit him in London three times this year. There are a few references in the letters to tiredness, but no specific mention of illness other than a cold. ${ }^{41}$

In early March 1815, in a letter to her niece, Anna Lefroy, Jane seems to have been referring to an episode of illness. Unfortunately, most of the page has been torn away. Only a scrap remains at the bottom, and continues "I cannot flourish in this east wind, which is quite against my skin and conscience" ${ }^{42}$ Typically, she has trivialised her illness, and turned it into a joke.

Cold weather itch is quite common in winter, when the skin tends to become dry, and Jane seemed to be blaming the effect of the cold east wind on her skin. But itching, or pruritis, without skin rash, can be an early symptom of Hodgkin's disease, particularly in women. ${ }^{43}$ It is also a common complaint of patients with this disease and it has been reported that over $85 \%$ of patients will experience pruritis at some stage of their illness (Kaplan, p 120). ${ }^{37}$ "It is characterised by symptoms of burning and intense itching occurring on a localized skin area, usually the lower legs" (Cavalli, p 109)..$^{43}$ As the disease advances, the pruritis becomes generalized. The itching is severe enough to induce intensive scratching, leading to multiple, blood encrusted excoriations and scabs on the trunk and/or lower legs (Kaplan, p 120). ${ }^{37}$

Any further references to this illness have not survived. After this letter, there is a gap of 6 months before the letters begin again. In August 1815 Jane Austen began work on Persuasion. The writing would continue somehow through increasing bouts of illness and family problems.

A family crisis occurred in October, when Henry Austen suffered a life threatening illness. His sister Jane was staying with him in London at the time, whilst he helped her to arrange the publication of Emma. She wrote to Cassandra on 17 October, describing Henry as "not quite well - a bilious attack with fever." ${ }^{44}$ Cassandra seems to have destroyed the letters that quickly followed, with their details of Henry's deterioration and danger. Just 1 week later, Henry was thought to be dying. His brothers Edward and James and sister, Cassandra, came immediately to London and the brothers were there a week until Henry was out of danger. Cassandra however, was away from Chawton for a month, which must have been extremely inconvenient for James
Austen's wife, Mary, who had to stay with Mrs Austen until Cassandra's return. ${ }^{45}$ This arrangement could only be justified if Jane was also ill or at least not well enough to nurse her brother. Jane's illness seems to be confirmed by Caroline Austen's report that "In the earlier stages of her malady, my Aunt had had the advice, in London, of one of the eminent physicians of the day" (Austen, p 15). ${ }^{26}$ This was probably Dr Matthew Baillie, who was treating Henry Austen in this illness, and was one of the Prince Regent's physicians (Le Faye, p 225). ${ }^{3}$ She may have consulted him about the pruritis, and other unspecified symptoms. Emma was published at the end of December, 2 weeks after Jane had returned to Chawton, and she never visited London again.

Henry Austen in his Biographical Notice of Jane Austen wrote that "the symptoms of a decay, deep and incurable, began to show themselves in the commencement of 1816. Her decline was at first deceitfully slow; and until the spring of this present year [1817], those who knew their happiness to be involved in her existence could not endure to despair" (Austen, p 138). ${ }^{1}$

Biographers have accepted this dating as the beginning of her illness, but it can also be interpreted as the date when family members realised that something was seriously wrong. Her niece Caroline also considered that "Aunt Jane's health began to fail some time before we knew she was really ill" (Austen, p 13). ${ }^{26}$ In March 1816, there was a new family crisis when Henry Austen was declared bankrupt following the sudden failure of his London bank, and his brothers suffered heavy losses as well" (Austen, p 47)..$^{45}$ Jane's health also was deteriorating. At the beginning of May, Edward Knight and his daughter Fanny came to Chawton cottage for 3 weeks, but Jane was too weak to accompany Cassandra and Fanny on their daily walks. The day after the Knights returned to Kent, Jane and Cassandra set off to try the spa waters of Cheltenham for 2 weeks. Johanna Schopenhauer, who visited Cheltenham in this Regency period, noted in her travel diary that this spa catered especially for those with "skin ailments, scurvy and such complaints." ${ }^{46}$ Jane may have been seeking treatment for her skin and the worsening problem of the pruritis.

On their way home, the sisters paid a visit to very old friends, the Fowle family at Kintbury. During their stay, the family "received an impression that Jane's health was failing - altho' they did not know of any particular malady" (Austen, page 14). ${ }^{26}$ When they returned home on 15 June, Jane was even weaker and needed the donkey carriage to move about. In July, she attributed a pain in her back to her distress on Cassandra going away for a few weeks. Despite her illness, she completed Persuasion in August. In September, the family called in a well-known physician, Dr. White, for his opinion. Typically, Jane laughed about this visit, and intended "nursing myself up now, into as beautiful a state as I can." ${ }^{\prime \prime 7}$

Through the first months of winter, she felt that she was improving, and this is quite consistent with the progress of Hodgkin's disease. On 23 January 1817, Jane noted that she was "getting stronger than I was half a year ago," 48 and a letter to a close friend the following day is just as optimistic. She added, "I am more and more convinced that Bile is at the bottom of all I have suffered, which makes it easy to know how to treat myself." 49

Three days later, in this spirit of optimism, she began work on a new novel, the fragment now known as Sanditon, and worked steadily through February and into March.

On 20 February she wrote to her favourite niece Fanny that "I am almost entirely cured of my rheumatism; just a little pain in my knee now and then, to make me remember what it was and keep on flannel, - Aunt Cassandra nursed me so beautifully." ${ }^{50}$ On 13 March she wrote hopefully "I am got 
tolerably well again," ${ }^{\prime 51}$ but on 18 March she abandoned the manuscript after a severe bout of illness.

On 23 March she wrote to Fanny again, including a description of other and distressing symptoms:

Many thanks for your kind care for my health; I certainly have not been well for many weeks, and about a week ago I was very poorly, I have had a good deal of fever at times and indifferent nights, but am considerably better now, and recovering my Looks a little, which have been bad enough, black and white and every wrong colour. ${ }^{52}$

The rest of this long letter is full of family news and good humour, and characteristically begins with a joke. But just l week later, there was another severe episode of "Bilious attack, attended with a good deal of fever", and Jane's letter to her brother Charles on 6 April attributes this "relapse" of her "complaint" to the shock of her uncle's will. ${ }^{53}$

Jane's 12 year old niece, Caroline Austen, saw her, for the last time, during the early part of April. Aunt Jane was keeping to her room, and the visit was a very short one. "I was struck by the alteration in herself - She was very pale - her voice was weak and low and there was about her, a general appearance of debility and suffering" (Austen, p 15). ${ }^{26}$ A few days after Caroline's visit, there was another episode of fever, which Jane described in her letter of Thursday 22 May:

An attack of my sad complaint seized me . . . the most severe I ever had - and coming upon me after weeks of indisposition, it reduced me very low. I have kept my bed since the 13. of April, with only removals to a Sopha. Now, I am getting well again, and indeed have been gradually tho' slowly recovering my strength for the last three weeks. I can sit up in my bed \& employ myself . . . My head was always clear, and I had scarcely any pain; my cheif sufferings were from feverish nights, weakness and Languor. - This Discharge was on me for above a week, \& as our Alton Apoth did not pretend to be able to cope with it, better advice was called in. Our nearest very good is at Winchester, where there is a Hospital and capital Surgeons, and one of them attended me, and his applications gradually removed the Evil. - The consequence is, that instead of going to Town to put myself into the hands of some Physician as I should otherwise have done, I am going to Winchester instead. ${ }^{54}$

Despite the optimistic tone of this letter, she had secretly written her will on 27 April, and left it, unwitnessed, in her writing case (Le Faye, p 248). ${ }^{3}$ On 27 May, she wrote cheerfully from Winchester, but in a shaky, uneven hand. "I will not boast of my handwriting; neither that nor my face have yet recovered their proper beauty, but in other respects I am gaining strength very fast." ${ }^{\prime 55}$ Two days later she states that:

My attendant is encouraging, and talks of making me quite well. I live chiefly on the sofa, but am allowed to walk from one room to the other. ${ }^{56}$

But immediately after this letter, the fever returned again. Jane's brother James made frequent visits to Winchester, and wrote to his son, James Edward, on 12 June, preparing him for news of Jane's death.

The symptoms which returned after the first four or five days at Winchester [30 May] have never subsided, and
Mr. Lyford has candidly told us that her case is desperate. . .. It is some consolation to know that our poor invalid has hitherto felt no very severe pain - which is rather an extraordinary circumstance in her complaint. I saw her on Tuesday [10 June] and found her much altered, but composed and cheerful. She is well aware of her situation ... Lyford said he saw no signs of immediate dissolution, but added with such a pulse it was impossible for any person to last long. ${ }^{57}$

But the following day:

Suddenly she became much worse - Mr. Lyford thought the end was near at hand, and she believed herself to be dying - and under this conviction she said all she wished to say to those around her (Austen, pp 16-17). ${ }^{26}$

The youngest brother Charles, who had been summoned urgently from London, arrived early on 13 June to find "my sister very ill" but notes on 15 June, "Jane a shade better." He made another diary entry on 19 June before returning to London; "Jane a little better. Saw her twice and in the evening for the last time in this world as I greatly fear, the Doctor having no hope of her final recovery" (Le Faye, pp 251-2). ${ }^{3}$

On 19 June also, Mrs. Austen passed on the latest report from Winchester.

Jane has had a better Night than she has had for many weeks, and has been comfortable all day, Mr. Lyford says he thinks better of her than he has ever done, tho must still consider her in a precarious state. ${ }^{58}$

Caroline Austen recorded that: "Contrary to any expectation . . . Aunt Jane continued very cheerfully and comfortable, and there began to be a hope of, at least, a respite from death". During these months of illness, Jane's "sweetness of temper never failed her; she was considerate and grateful to those who attended on her, and at times, when feeling rather better, her playfulness of spirit prevailed, and she amused them, even in their sadness . . . I need scarcely say she was dearly loved by her family (Austen, pp 16-17). ${ }^{26}$

On Monday 14 July Mrs Austen wrote again to Anna "Charles Knight came this morning: he saw her [Jane] yesterday, and says she looked better and seemd very cheerful" ${ }^{59}$ The following morning, St.Swithin's Day, Jane felt energetic enough to compose some comic verses about the saint, which she dictated to Cassandra. But that same evening the fever returned. Cassandra noted "a visible change, she slept more and much more comfortably, indeed during the last eight and forty hours she was more asleep than awake. Her looks altered and she fell away." Late on Thursday afternoon Cassandra returned from an errand to find Jane recovering from a "seizure" of "faintness and oppression." Another quickly followed, and she suffered for about half an hour before Mr Lyford arrived and "applied something to give her ease and she was in a state of quiet insensibility" that continued until her death in the early hours of the following morning. ${ }^{60} \mathrm{Mr}$ Lyford supposed some large blood vessel had given way. ${ }^{61}$

Sir Zachary Cope, in an article in the British Medical Journal in 1964, was the first to offer a diagnosis of Jane Austen's illness. ${ }^{62}$ He considered that she was suffering from Addison's disease, secondary to Tuberculosis of the suprarenal glands, in which fatigue, increasing weakness, and crises or relapses in times of mental stress, are characteristic 
symptoms. Night fevers, however, are not symptoms of Addison's disease, as a correspondent, FA Bevan, pointed out in the following issue of the journal. Bevan suggests an alternative diagnosis of Hodgkin's disease, "could account for all the symptoms mentioned, including the skin pigmentation and the initial pain in the back." He cites the case of his own patient, with confirmed lymphadenoma, whose disease, "which was without marked enlargement of superficial lymph nodes, ran a similar acute course to Jane Austen's." ${ }^{63}$ Despite this immediate challenge to Cope's diagnosis of Addison's disease, his article has been cited in Austen biography and literary studies for the past 40 years, and Addison's disease is generally accepted as the cause of her fatal illness. The new edition of Le Faye's authoritative biography of Jane Austen, published in the past year, again cites Cope, and repeats his claim "that early in 1816 she [Austen] fell victim to the then unrecognised Addison's Disease" (Le Faye, p 236). ${ }^{3}$

Cope points to evidence of Addisonian crises, triggered by emotional stress, and considers that Jane's disease was "precipitated" by the "severe mental shock" of Henry Austen's bankruptcy in March 1816. But the existing medical evidence supports a much earlier date for the commencement of her fatal disease. He also considers that the shock of her uncle's will brought on another Addisonian crisis in April 1817. In fact this episode is not a relapse or crisis, but part of a cyclical pattern of fever which can be traced from early February 1817, and continued until her death.

Jane's own letters in the last 4 months of her life, documenting these periods of night fever of 1 or more weeks, which she described as her "complaint", alternating with similar afebrile periods, provide evidence that she suffered from Hodgkin's disease. This cyclic pattern of fever, known as the Pel-Ebstein fever, is "a classic clinical sign in Hodgkin's disease ... When fever occurs, it usually peaks in the evening, and falls precipitously in the early morning hours, resulting in drenching night sweats." ${ }^{\prime 64}$ It is also associated with significant haemolysis, and an autoimmune haemolytic anaemia (Kaplan, p 121). ${ }^{37}$ Kaplan suggests that there is increased red blood cell destruction during periods of high fever, and refers to a study which measured the mean loss of haemoglobin in a fever period as 14 percent. This finding is consistent with Jane's increasing weakness after each attack. Pel-Ebstein fever is an ominous symptom, indicating "far advanced disease" (Kaplan, p 117), ${ }^{37}$ and a standard reference describes it as "virtually diagnostic of Hodgkin's disease." ${ }^{\prime 65}$

Cope considers that Jane's description of her face in March, 1817, as being 'black and white and every wrong colour' is "almost pathognomonic of Addison's disease" (Cope, p 272). ${ }^{62}$ The hyperpigmentation or tanning of the skin associated with Addison's disease, however, is inconsistent with her being described as "very pale" shortly afterwards in April (Austen, p 15). ${ }^{26}$ Cope also suggests that "there is no disease other than Addison's disease that could present a face that was "black and white" and at the same time give rise to the other symptoms described in her letters" (Cope, p 272). ${ }^{62}$ He had overlooked Hodgkin's disease.

Idiopathic thrombocytopenia purpura, is a rare syndrome associated with Hodgkin's disease (Cavalli, p 111). ${ }^{43}$ and is a further haematologic complication that may occur in the advanced or terminal stage of the disease. ${ }^{66}$ It may affect the face and can be devastating to the patient. ${ }^{67}$ The symptoms begin with a scattering of red spots, which gradually progress to purple, then darken again, and in some cases turning black. A few days later the spots gradually begin to resolve, and change in colour like a bruise, turning green before fading to a yellowish brown and disappearing. This is consistent with Jane's letter of 25 March describing her looks as "recovering again," and in April, they had gone completely when she was described as "very pale." The "black and white and every wrong colour" of her face describes this process in contrast to the underlying severe anaemia. New crops may soon appear and the process begins again, and in Jane's letter of 27 May, the purpura had returned. ${ }^{68}$

Tuberculosis was frequently associated with Hodgkin's disease in the 19th Century, with pathologists observing Tuberculosis in about $20 \%$ of autopsies on patients with Hodgkin's disease. One authority of this period considered that "tuberculosis follows Hodgkin's disease like a shadow," and it is possible that Jane had this disease as well as the fatal lymphoma (Kaplan, p 236). ${ }^{37}$

Jane Austen's biographers have seriously underestimated the extent to which illness affected her, throughout her life, and mistakenly continue to describe her fatal illness as Addison's disease. While no strict proof is available, there is a high possibility that a lymphoma such as Hodgkin's disease caused her early death. This disease, unknown in Jane's lifetime, was identified by the work of Thomas Hodgkin in 1832. Her final letters, written some fifteen years earlier, with their clear, observant assessment of her symptoms, may describe the first recorded case of Hodgkin's disease.

\section{ACKNOWLEDGEMENTS}

I wish to acknowledge the substantive contribution of Ian Frazer to this paper, in his kind assistance in discussing the issues involved, and suggested revisions to the manuscript.

Professor Ian Frazer, FAA FTSE MBChB(Edin) MD(Melb) FRCPAD FRCPA Professor/Director, Centre for Immunology and Cancer Research, University of Queensland, Australia.

\section{REFERENCES}

1 Austen H. Biographical Notice of the Author. In: Sutherland Kathryn, eds. A Memoir of Jane Austen and Other Family Recollections. Oxford: Oxford University Press, 2002:138.

2 Tomalin C. Jane Austen: A Life. London: Viking, 1997:256.

3 Le Faye D. Jane Austen: A Family Record [new ed]. Cambridge: Cambridge University Press, 2004:235.

4 Le Faye D, ed. Jane Austen's Letters [3rd ed]. Oxford: Oxford University Press, 1995:xv.

5 Austen-Leigh JE. A Memoir of Jane Austen. Oxford: Clarendon Press, 1926:43.

6 Letter. Austen, George to Susanna Walter, 17 December 1775. In: Austen Leigh RA, ed. Austen Papers: 1704-1856, London: Pottiswoode, Ballantyne \& Co, 1942:32.

7 Sims ME, Walther FJ. Neonatal Morbidity and Mortality and Long- term Outcome of Postdate Infants. Clinical Obstetrics and Gynaecology 1989;32:285.

8 Clifford SH. Postmaturity with placental dysfunction. Journal of Paediatrics 1954;44:1.

9 Beers MH, Berkow R, eds. The Merk Manual of Diagnosis and Therapy [17th ed]. New Jersey: Merck Research Laboratories, 1999:2130.

10 Letter. Austen, George to Susanna Walter. 17 Dec. 1775. See reference 6, 32-33.

11 Letter. Austen, Mrs. Cassandra. to Mrs. Walter, 20 August 1775. See reference 6, 31

12 Letter, Mrs. Cassandra Austen to Susanna Walter, 6 June 1773. See reference 6, 29.

13 Letter, Woodman, John to Warren Hastings, 11 June 1776. See reference 6, 82.

14 Chapman RW. Facts and Problems. Oxford: Clarendon Press, 1948:23.

15 Austen-Leigh MA. Personal Aspects of Jane Austen. Folcroft, Pa: Folcroft Library Editions, 1974:22.

16 Macpherson G, ed. Black's Medical Dictionary [37th ed]. London: Black, 1992:604.

17 Mc Phee J, Pupadakis A, Tierney L, eds. Current Medical Diagnosis and Treatment. New York: McGraw Hill, 2001:1341.

18 Austen Jane. Sense and Sensibility. London: Penguin Classics, 1995:287.

19 Letter, Jane to Cassandra Austen, 8-9 January 1799. In: Jane Austen's Letters: [3rd ed], Collected and Edited by Deirdre Le Faye. Oxford: Oxford University Press, 1995:33-34.

20 Letter. Jane to Cassandra Austen, 21-23 January 1799. See reference 19, 36.

21 Barza M, Baum J. Infectious Conjunctivitis. Infectious Disease Clinics of North America 1992;6:798

22 Lefter. Jane to Cassandra Austen, 8-9 January 1799. See reference 19, 35. 23 Letter. Jane to Cassandra Austen, 21-23 January 1799. See reference 19,
36. 
24 Letter. Jane to Cassandra Austen, 17 May 1799. See reference 19, 41

25 Letter. Jane to Cassandra Austen, 16 September 1813. See reference 19, 222.

26 Austen C. My Aunt Jane Austen [new ed]. Winchester: Jane Austen Society, 1991:7.

27 Austen-Leigh W, Austen -Leigh R. Jane Austen: Her Life and Letters, A Family Record [2nd.ed]. New York: Russell, 1965:155-6.

28 Letter. Henry Austen to Frank Austen 28 Jan 1805, and Letter, James Austen to Frank Austen 30 Jan 1805. See reference 6, 234-6.

29 Letter. Jane to Cassandra Austen, 1-2 October 1808. See reference 19, 138

30 Letter. Jane to Cassandra Austen, 7-8 January 1807. See reference 19, 114-5.

31 Letter. Jane to Cassandra Austen, 1-2 October 1808. See Reference 19, 140

32 Letter. Jane to Cassandra Austen, 7-9 October 1808. See reference 19, 144

33 Le Faye D. Fanny Knight's Diaries: Jane Austen Through Her Nieces's Eyes. Winchester: The Jane Austen Society, 2000:27.

34 Letter. Jane to Cassandra Austen, 15-16 September 1813. See reference 19, 220.

35 Letter. Jane to Cassandra Austen, 23-24 September 1813. See reference 19, 226.

36 Letter. Jane to Cassandra Austen, 23-24 September 1813. See reference 19, 224-8.

37 Kaplan H. Hodgkin's Disease [2nd ed]. Cambridge, Mass: Harvard University Press, 1980:145.

38 Maung ZT, et al. Patient education for self-referral and on-demand treatment for herpes zoster in lymphoma patients. Leukemia and Lymphoma 1993; 11:447-52.

39 Cartwright RA, Watkins G. Epidemiology of Hodgkin's Disease: A Review. Hematological Oncology March, 2004;22:15.

40 Harris NL. The many faces of Hodgkin's disease around the world: What have we learned from its pathology? 4th International Symposium on Hodgkin's Disease. Annals of Oncology 1998;9(Suppl.5):s45-56.

41 Letter. Jane to Cassandra Austen, 9 March 1814. See reference 19, 262.

42 Letter. Jane Austen toAnna Lefroy, late February- early March 1815. See reference 26, 289.

43 Cavalli F. Rare Syndromes in Hodgkin's Disease. 4th International Symposium on Hodgkin's Disease. Annals of Oncology 1998;9(Suppl.5):s109-13.

44 Letter. Jane to Cassandra Austen, 17-18 October 1815. See reference 19, 291.

45 Austen C. Reminiscences of Caroline Austen. Le Faye D, Introduction and Notes. Winchester: Jane Austen Society, 1986:46-7.
46 Sales R. Jane Austen: Representations of Regency England. London: Routledge, 1994:206.

47 Letter. Jane to Cassandra Austen, 8-9 September 1816. See reference 19, 320.

48 Lefter. Jane to Caroline Austen, 23 January 1817. See reference 19, 326.

49 Letter. Jane Austen to Alethea Bigg, 24 January 1817. See reference 19, 326-7.

50 Letter. Jane Austen to Fanny Knight, 20 February 1817. See reference 19, 329.

51 Letter. Jane Austen to Fanny Knight, 13 March 1817. See reference 19, 333.

52 Letter. Jane Austen to Fanny Knight, 23-25 March 1817. See reference 19, 335.

53 Letter. Jane Austen to Charles Austen, 6 April 1817. See reference 19, 338

54 Letter. Jane Austen to Anne Sharp, 22 May 1817. See reference 19, 340.

55 Lefter. Jane Austen to James Edward Austen, 27 May 1817. See reference 19, 342.

56 Letter. Jane Austen to Frances Tilson? 29 May 1817. See reference 19, 343.

57 Letter. James Austen to J. E. Austen-Leigh, 12 June 1817. See reference 27, 392-3.

58 Lefter. Mrs Cassandra Austen to Anna Lefroy, 19 June 1817. See reference 3, 251.

59 Letter. Mrs Cassandra Austen to Anna Lefroy, 14 July 1817. See reference $19,253$.

60 Letter. Miss Cassandra Austen to Fanny Knight, 20 July 1817. See reference $19,344-5$.

61 Letter. Mrs Cassandra Austen to Fanny Lefroy, 19 July 1817. See reference 3, 253.

62 Cope Z. Jane Austen's Last Illness. Reprinted from BMJ July 1964 in Jane Austen Society Collected Reports 1(1949-65); Alton. 267-72.

63 Bevan FA. [Letter to ed]. British Medical Journal 1964:384.

64 Austen KF, et al. eds. Samter's immunologic diseases. Vol. 1. [6th ed]. Philadelphia: Lippincott Williams \& Wilkins, 2001:362

65 In: Humes HD, ed. in chief. Kelly's Textbook of Internal Medicine [4th ed] Philadelphia: Lippincott Williams and Wilkins, 2000:1691.

66 Fernandoz O, Morales E, Toledo J. Autoimmune Processes Terminating 24 Years in Hodgkin's Disease. British Journal of Haematology 1992:81:308.

67 Goldman AC, et al. Facial Purpura. The Laryngoscope 2001 Feb;111(2):209

68 Letter. Jane Austen to James Edward Austen, 27 May 1817. See reference 26, 342

\section{bmjupdates+}

bmiupdates+ is a unique and free alerting service, designed to keep you up to date with the medical literature that is truly important to your practice.

bmjupdates+ will alert you to important new research and will provide you with the best new evidence concerning important advances in health care, tailored to your medical interests and time demands.

Where does the information come from?

bmjupdates+ applies an expert critical appraisal filter to over 100 top medical journals A panel of over 2000 physicians find the few 'must read' studies for each area of clinical interest

Sign up to receive your tailored email alerts, searching access and more...

www.bmjupdates.com 